rejects the idea of any form of national water grid as impracticable, but agrees that regional arrangements might well prove useful and desirable. The hydrologists who have consistently stressed the importance of the river basin as the natural administrative unit will welcome the recognition at long last of this fundamental starting point for reorganization. Strangely, however, this view was not taken by all the water authorities and organizations which submitted evidence.

While the Sub-Committee was united in the view that a major reorganization of the control of Britain's water resources along the lines indicated is desirable, it divided as to the means whereby this could be achieved. The majority report proposed the creation of completely new River Authorities limited to small, compact and working groups of 10-15. These new Authorities would be responsible for conservation and also assume the functions of, and supersede, the existing River Boards. There is a minority report, however, of six out of the sixteen members in favour of reconstituting the existing River Boards as integrated River Authorities. The majority of the Sub-Committee think that this method would create very large and unwieldy bodies as membership might rise to more than 40 . The existence of the River Boards (at present charged with land drainage and flood control) is clearly a very vital factor in the situation.

The Sub-Committee also emphatically recommends the creation of a central authority, accountable to the Minister of Housing and Local Government, to promote an active policy for the conservation and proper use of water resources, and to ensure that the River Authorities carry it out efficiently. A national view of the developing situation is now increasingly being demanded as the growing conurbations seek their water ever farther afield, and more often than not in areas designated as National Parks. Water conservation and national parks are not irreconcilable, but the public needs reassurance that the right decisions are being made as to the proper allocations between competing land users. Only a central authority can collate and co-ordinate data and under- take research that will provide from year to year a national appraisal of water requirements and the best ways of meeting those needs.

The need for a comprehensive and integrated land drainage, water conservation and flood control management policy was amply demonstrated during the period in which the Sub-Committee was sitting. The summer of 1959 was the driest for nearly 250 years and many water undertakers were unable to meet the demand, some industries were forced to close down and there was considerable inconvenience in the north and west of Britain, where reliance is placed more on surface waters than on underground storage. The fall in river-levels affected navigation, stopped fishing, reduced irrigation and increased pollution. By contrast 1960 was the third wettest year for 250 years and the rainfall during the late summer and autumn was the heaviest on record for England and Wales. Widespread flooding resulted in the absence of regulating reservoirs. These events coming in such close juxtaposition had a significant impact on the public and there was a widespread realization that Britain ought to be able to manage her affairs better. The final report of the Sub-Committee on the Growing Demand for Water now directs the way to better management. Without this reorganization the continued economic development of Britain will be imperilled and further Tryweryn and Ullswater battles may be expected to occur with increasing frequency. It is to be hoped that the Minister and the Government will find time to introduce the necessary legislation without delay and not wait until the next drought or flood crisis is on the country. The setting up of the River Authorities and the emergence of a national appraisal will take some years even if the task is regarded as urgent. Meanwhile, the insurance against drought diminishes yearly as both the population and the standard of living rises. W. G. V. BALCHIN

${ }^{1}$ Nature 172, 263, 823 (1953); 176, 1133 (1955); 184, B.A., 18 (1959).

${ }^{2}$ Central Advisory Water Committee. Sub-Committee on the Growing Demand for Water-Final Report. Pp. iii +43 . (London: H.M.S.O. 1962) $3 s, 6 d$ net.

${ }^{3}$ Nature, 191, 421 (1961).

\title{
PLANKTON INDICATOR SPECIES AND THEIR STATISTICAL ANALYSIS
}

T HE study of plankton indicator organisms in relation to water masses and the fisheries usually involves much subjective reasoning and assumption. Typically". only the presence or absence of certain forms is considered, or the percentage composition of the arrow-worm population (Sagitta species). There has always been great difficulty in using exact analy. ses, in part because of the poor sampling qualities of conventional nets, but also because in the study of small areas the result is a purely temporal distribution, much more awkward to assimilate than the simple contoured maps of a spatial distribution.

The work described in a recent series of papers* represents the start of more objective methods in

*Bulletins of Marine Ecology, formerly Hull Bulletins of Marine Écology, Nos. 47 and 48, Vol. 5 : An Ecological Survey of a Scottish Herring Fishery. Part 3 : Geographical and Ecological Groups in the Plankton. By R. S. Glover, G. A. Cooper and D. C. T. Forsyth. Part 4: Changes in the Plankton during the period 1949 to 1959 . By Dr. M. H. Williamson. Appendix: A Method for Studying the Relation of Plankton Variations to Hydrography. By Dr. M. H. Williamson. Pp. 195-229. (Edinburgh: The Scottish Marine Biological Association). 98 . the study of samples from a small area. Some errors of conventional sampling have been removed by the use of high-speed samplers, in this case modifications of the small 'Hardy indicator' capable of being used from any vessel in the herring fleet. Further errors between day and night samples as a result of diurnal migration and evasion of nets have been minimized by omitting day samples. The results are presented as the average abundance per sample at night in summer for each of the ten years 1949-59.

Dr. M. H. Williamson has taken the figures of average abundance, and by using ranking methods (Spearman's coefficient is preferred) has derived primary and secondary correlation matrices showing the degree of relationship between years and between species. With one or two exceptions the organisms fall into four groups. Two of them $(B$ and $M)$ are regarded as not being geographical assemblages, but the others are recognized as neritic $(A)$ and oceanic ( $Z$ - " $a$ centre of distribution towards the edge of the continental shelf"). In the appendix, the matrices of 
correlations are transformed by principal component analysis and the resulting vectors compared by ranking methods with hydrographic features, some of which, however, are of rather subjective meaning (Craig's "oceanic influence" and "spring anomaly"). More than half the variation in plankton from year to year would appear to be connected in some way with hydrographic events occurring in the spring, and only 10 per cent with possible oceanic influence.

Messrs. Glover, Cooper and Forsyth discuss the average abundance of the organisms arranged subjectively in the order neritic-oceanic in comparison with the grouping found by Williamson. Although there is some agreoment considerable differencos exist, particularly the status of spocies of group $Z$, which they class as intermediate, not oceanic. The so-called oceanic forms are discussed in comparison with thoir distribution in tho north-east Atlantic and North Sea, as shown by continuous recorder sampling. It emerges that many 'oceanie' species vary in the extent to which they occur in the ocean from year to year, and hence many of the changes taking place in the North Sea, although obviously related to changes outside, can no longer be regarded as due to variations in the strength of inflow of oceanic water. However, the authors do not take their discussion further than this, and continue to stress the importance of oceanic water to fisheries.

One criticism must be made: in both contributions biogeography is considored only from the point of view of oceanic-neritic differences, and north/south or other temperature differences are not mentioned. Hence, for example, an attribution oceanic to a species could cover any category from arctic to tropical according to the depth (and temperature range) at which it was abundant. This difficulty is increased by the need to combine certain species. The grouped cuphausids, for example, include arctic/boreal forms such as Thysanoessa and Meganyctiphanes as well as tho sub-tropical/temperate Nyctiphanes. This aspect should surely be taken into account in attempts to unravel the complexities of plankton distribution in relation to the pelagic fisheries.

A. J. SOUTHWARI

\title{
RESEARCH IN INDUSTRY
}

\begin{abstract}
TNDUSTRIAL Research in Manufacturing Industry, 1959-60*, has been prepared by the Federation of British Industries in conjunction with the National Institute of Economic and Social Research. It is the first investigation to attempt a qualitative as well as a quantitative analysis of rosearch and development in British manufacturing industry. C. Freoman and R. W. Evely, of the National Institute of Economio and Social Research, worked for a year in analysing questionnaires and samples which would provide information on the research pattern in different industries, the breakdown of research expenditure into basic and applied research, the growth of research departments in different industries, the effect of Government expenditure on research in industry and the relationship of research to growth. On the basis of this information two commentaries were written, one by Prof. Bruce Williams on behalf of the National Institute of Economic and Social Research and one by G. A. Dummett, the chairman

* Federation of British Industries. Industrial Research in Manufacturing Industry 19.5.4-60: Results of a Survey including Commentaries and a Statístical Report. Pp. 129. (London: Federation
of British Industries, 1961.) 40s.
\end{abstract}

of the Industrial Research Committee of the Foderation of British Industries.

The survey shows that as much expenditure is being devoted to basic research and new products as to improvements in existing products and processes. Despite the fact that the science-based industries and large firms account for most of the recent expansion in rosearch, there has been a greater relative increase in industries with lower research ratios and among the medium and small-sized firms. One example in the attempt to correlate research expenditure and the growth of the firm shows that, in chemicals, five firms out of the twenty-two selected which grew fastest in terms of total not assets had a level of internal expenditure on research and develop. ment $2 \frac{1}{2}$ times as large as the five firms which grew least.

Nearly one in ten of all, and one in four of large, respondent firms have direct Government research contracts. On the deficiencies which the survoy shows up, the most important limitation on expansion of research activity is the lack of qualified manpowerthere is a standing vacancy of about 13 per cent overall in industry's rescarch and development departments.

\section{SCINTILLATIONS OF RADIO STARS AND SATELLITES DURING INTENSE MAGNETIC DISTURBANCES}

\author{
By W. KIDD, H. SILVERMAN, H. WHITNEY and J. AARONS \\ U.S. Air Force Cambridge Research Laboratories, Bedford, Mass.
}

\begin{abstract}
$\mathrm{A}^{\mathrm{N}}$ $\mathrm{N}$ unusual relationship betwoen the received als from the discrete sources Cygnus $A$ and Cassiopeia $A$ was noted when results were recorded simultanoously at 62,109 and $226 \mathrm{Me} / \mathrm{s}$. during several
\end{abstract}

periods of intense magnetic disturbance (local magnotic index ${ }^{1} \geqslant 6$ ). These investigations wore made with the 84-ft. parabolic antenna of the Air Force Cambridgo Research Laboratories' Sagamore Hill Radio Observatory at a geographical latitude of 